\title{
Urban space and the literary exploration of self - A rhetorician makes a mental tour through his city
}

\author{
Samuel Mareel
}

Between 14 May 1561 and the beginning of the following year, Eduard de Dene, a poet and legal clerk from the Flemish city of Bruges, copied out 465 folios of his own poems and songs in what he called his Testament Rhetoricael ['Rhetorical Testament' or 'Testament in verse']. Probably because it was so extensive, the collection was never printed. The autograph did, however, come down to us and constitutes one of the generically most varied and aesthetically most attractive collections of sixteenth-century Dutch poetry and song known today. ${ }^{1}$

Of particular value in the Testament Rhetoricael are not only its diversity and literary quality but also its outspoken autobiographical nature. The major part of De Dene's poetical compositions conforms in both form and content to the literary conventions of the art of the rhetoricians. The collection contains refreinen [refrains], ballades, songs, rondeaux, and chronograms that praise the Virgin Mary, Charles V, the Holy Sacrament, fellow rhetoricians, and the art of rhetoric; they also abuse the French, heretics, liars, and the haughty, and mock misers and henpecked husbands. What sets De Dene's manuscript apart from most other Dutch lyrical collections from the period, however, is the integration of the poems and songs in a kind of meta-narrative. This framework evokes the author's persona drawing up his last will and testament. Most of his bequests are literary compositions of his own making. The majority of the beneficiaries can be situated in mid-sixteenth-century Bruges, the time and place in which De Dene lived, worked, and wrote. Because of the wealth of information it provides in its testamentary framework, the Testament Rhetoricael constitutes a unique testimonial to the biography, ideas, opinions, and social world of a middle-class author in a mid-sixteenth-century urban environment.

\footnotetext{
${ }^{1}$ Eduard de Dene, Testament rhetoricael, ed. Werner Waterschoot and Dirk Coigneau, 3 vols. (Ghent: Koninklijke Soevereine Hoofdkamer van Retorica 'De Fonteine', 1976-1980) [Jaarboek 'De Fonteine', 26, 28, and 30 (1976-1980)]. Unfortunately De Dene's verse is not (yet) available in English translation. Readers with some knowledge of Dutch can consult a generous selection of poems and songs from the Testament rhetoricael, with translation in modern Dutch, in Gerrit Komrij, De Nederlandse pö̈zie van de $12^{\text {de }}$ tot en met de $16^{\text {de }}$ eeuw in 1000 en enige bladzijden (Amsterdam: Bert Bakker, 1994), 908-57. On De Dene and his Testament rhetoricael, see also the essay by Alisa van de Haar elsewhere in this issue.
} 
A second remarkable feature of the Testament is the fact that De Dene's representation of self is prominently linked to that of Bruges' urban space. The author's autobiographical utterances are generally part of an evocation of buildings and locations. When he says something about himself he tends to do this as part of a description of a place or a building. This is most obvious in the first half of the Testament, in which De Dene's persona evokes a number of Bruges churches, monasteries, and official buildings. While doing so he bequeaths poems and, to a lesser extent, objects, both concrete and imaginary, and abstract intentions. These are addressed to a large and diverse array of beneficiaries that are in some way related to these institutions. At the church of Our Lady, for example, he bequeaths a Lof [Praise] to the Holy Sacrament to the chapel of the guild of the Holy Sacrament, ${ }^{2}$ and a refereyn on Mary Magdalene, Saint Catherine, and Saint Barbara to the altar of the chamber of rhetoric of De Drie Santinnen [The Three Female Saints], which was located in the same chapel. ${ }^{3}$ The clerk of De Drie Santinnen, who is responsible for the maintenance of the chapel, receives another refrain on the same subject. ${ }^{4}$ For the impoverished 'Ian drooghkele' [John with the dry throat], a 'groot mout docteur' [great doctor in the science of the malts], De Dene wishes that he may possess a room, a kitchen, a bar, a happy wife, and a job in a brewery. As we learn from the same poem 'Ian drooghkele' was a drinking buddy of the author but also a valuable artist who plays the organ of the church when he is not in prison. ${ }^{5}$ While making his bequests the poet reminisces about his personal relationship to these places and buildings and to the people he used to know there. At the Bruges church of the Holy Cross, for example, he tells us that he once lived in that parish, and at the city hall that he was married there. ${ }^{6}$

The converging force between self and space in the Testament Rhetoricael is memory. It is unclear if and to what extent De Dene was actually familiar with classical writings on the ars memorativa. ${ }^{7}$ Places do have a strongly mnemonic function in his text; they remind the author's persona of people and events from his past and trigger him to say something about himself. The medium in which these things are expressed is the literary text, the literary character in this case consisting of the use of verse and, frequently, of fiction.

This essay analyses Eduard de Dene's Testament Rhetoricael and the ways it brings together three domains of knowledge that were the object of increasing interest and study during the sixteenth century - of the individual self, of urban space, and of memory. It does this from the vantage point of what Elisabeth Hodges called 'urban poetics', and defined as 'the way the city functioned in

\footnotetext{
2 Ibid., I, 101.

3 Ibid., I, 103.

4 Ibid., I, 105.

5 Ibid., I, 107.

${ }^{6}$ Ibid., II, 205, 171.

7 Frances A. Yates, The Art of Memory (Chicago: University of Chicago Press, 1966); Mary Carruthers, The Book of Memory (Cambridge: Cambridge University Press, 1990).
} 
early modern texts as [...] a means by which authors expressed the self as a phenomenon related to location'. ${ }^{8}$ Hodges's study of 'urban poetics' builds on the work of Tom Conley, most notably his The Self-Made Map: Cartographic Writing in Early Modern France, in which Conley analysed how developments in cartography during the fifteenth and sixteenth centuries brought about an increased identification between self and space. ${ }^{9}$

An analysis of the 'urban poetics' of De Dene's Testament Rhetoricael can, as I hope to show, considerably advance our understanding of how the relationship between self and space was experienced and expressed in an early modern urban context. More generally, it can help us to read early modern literary texts as explorations of urban spatiality. The reason for this lies not only in De Dene's text being a little-known literary work but also in the extent to and detail in which it explores the link between the auctorial self and urban space. Its 465 folios contain such an amount of material that the collection could serve as the basis for both a topographical description of sixteenth-century Bruges and a modest biography of Eduard de Dene. In the pages that follow I look at De Dene's Testament through the lens of three early modern phenomena that can, I believe, give us a better insight into both the 'urban poetics' of De Dene's Testament Rhetoricael and, on a more theoretical level, the literary exploration of the relationship between knowledge of the early modern self and of early modern space: the genre of the literary testament, the emergence of cartography in an urban context, and the increasing use of literary texts in urban space for memorial purposes.

\section{THE LITERARY TESTAMENT}

As both the structuring principle and the author's own denomination indicate, ${ }^{10}$ De Dene considered his collection as a literary testament. This genre dates back to antiquity and was widely practised during the Middle Ages and the early modern period, both in Latin and in the vernacular. ${ }^{11}$ Literary testaments could vary widely in form, content, and tone. What mainly holds this

\footnotetext{
8 Elisabeth Hodges, Urban Poetics in the French Renaissance (Aldershot: Ashgate, 2008), 2-3.

${ }^{9}$ Tom Conley, The Self-Made Map: Cartographic Writing in Early Modern France (Minneapolis: University of Minnesota Press, 1996). On the link between identity and early modern urban space, see also the research that has been done on Italy, especially Venice and Florence, in, for example, Dennis Romano, 'Gender and the Urban Geography of Renaissance Venice’, Journal of Social History, 23 (1989), 339-53, and Lauro Martines, Strong Words: Writing and Social Strain in the Italian Renaissance (Baltimore: The Johns Hopkins University Press, 2003).

10 See, for example, De Dene, Testament, I, 32: 'Myn Rhetoricael testamentken cleene' [My modest rhetorical testament].

11 On the genre of the literary testament, see, for example, Winthrop Huntington Rice, The European Ancestry of Villon's Satirical Testaments (New York: The Corporate Press, 1941); Vladimir R. Rossman, Francois Villon: Les Concepts Medievaux Du Testament (Paris: Jean-Pierre Delarge, 1976); Ulrich Bach, Kommentierte Bibliographie englischer literarischer Testamente vom 14. bis zum 20. Jahrhundert (Heidelberg: C. Winter Universitätsverlag, 1982); Julia Boffey, 'Lydgate, Henryson, and the Literary Testament', Modern Language Quarterly, 53 (1992), 41-56; and Jacqueline Cerquiglini-Toulet, L'écriture testamentaire à la fin du Moyen Age: Identité, dispersion, trace (Oxford: Legenda, 1999).
} 
heterogeneous group of writings together is some form of playing around with the conventions of the legal will and testament. Literary testaments could thus invoke the disposition of goods by a testator, such as in the late antique (probably fourth century) Testamentum Porcelli [Little Pig's Will], ${ }^{12}$ or the making of a final confession, such as in the Testament of John Lydgate. ${ }^{13}$ They could call up the act of taking leave, for example, in the congés of the thirteenth-century jongleur Jean Bodel, ${ }^{14}$ or the giving of advice to the surviving next of kin, such as in the Uutersten Wille [Last Will] (1563), which the Piemontese businessman Lowys Porquin, who was based in the small town of Bergen op Zoom in North Brabant, addressed to his children. ${ }^{15}$

Some of the more interesting - and often longer and more complex - literary testaments combine several of these characteristics. The most famous and influential examples are François Villon's Le Lais (c. 1456), and especially his Grand Testament (1461), a 2000+ line virtuoso parody on the genres of both the legal and the literary testament. ${ }^{16}$ Although De Dene does not mention Villon as such, it seems, as Dirk Coigneau has convincingly argued, that the Lais and/or the Grand Testament have functioned as models for the Testament Rhetoricael. ${ }^{17}$ About a decade younger than the Testament Rhetoricael is the 'Wyll and Testament' (1573) by the English female poet Isabella Whitney. ${ }^{18}$ Any direct links between the Whitney and De Dene texts are highly unlikely. Yet, because of its comparable Villonesque mix-up of conventions and its obvious urban setting, in this case the city of London, the 'Wyll and Testament' provides interesting points of comparison to situate the Bruges text within a broader European context.

The borrowing of the conventions of the legal will and testament in literary texts often brought about a focus on the individual self. Jacqueline CerquigliniToulet pointed out the link between an emergence of the individual in the Middle Ages and a renaissance of the testament. 'Dans le domaine du droit', she argues, 'le testament est un champ d'affirmation de l'individu; en littérature, il est le lieu de construction d'une fiction de soi' [In the legal domain, the testament constitutes a field for the affirmation of the individual; in literature, it is a domain for the construction of a fiction of oneself]. ${ }^{19}$

The late medieval and early modern association of the testament with the individual self resulted both from its being the medium through which the

12 Edward Champlin, 'The Testament of the Piglet', Phoenix, 41 (1987), 174-83.

13 Boffey, 'Lydgate'.

14 Huntington Rice, European Ancestry, 158-63.

15 Myriam Greilsammer, Een pand voor het paradijs: Leven en zelfbeeld van Lowys Porquin, Pïmontees zakenman in de zestiende-eeuwse Nederlanden (Tielt: Lannoo, 1989).

${ }^{16}$ François Villon, Poésies, ed. Jean Dufournet (Paris: Gallimard, 1973).

17 Dirk Coigneau, 'Een Brugse Villon of Rabelais?: Eduard de Dene en zijn Testament Rhetoricael', in Bart Ramakers (ed.), Conformisten en rebellen: Rederijkerscultuur in de Nederlanden (1400-1650) (Amsterdam: Amsterdam University Press, 2003), 198-211.

18 Isabella Whitney, 'Wyll and Testament', in Renaissance Women Poets, ed. Danielle Clarke (London: Penguin Books, 2000), 18-28.

19 Cerquiglini-Toulet, L’écriture testamentaire, 5. 
individual disposed of his/her personal belongings and from the fact that the making of the last will was often combined with a final confession. This second characteristic brought about that wills increasingly contained passages of moral introspection. ${ }^{20}$ Both aspects are clearly present in De Dene's Testament. At the outset of the collection, for example, the poet evokes how, waking up hungry and broke one morning, he stumbles upon a note which he had previously written: 'memorare novissima [tua]' [be mindful of your last end]. ${ }^{21}$ This biblical quotation (Ecclesiasticus 7:40), often used in ars moriendi writings of the time, makes him reflect upon his numerous friends who have passed away and upon his own end. As a result he decides to draw up his testament, in which he will remember his deceased friends and bequeath all of his goods.

As Cerquiglini-Toulet indicated, the individual self-evoked in the literary testament was often a fiction, 'un phénomène de structure' [a structural phenomenon], as she called it. ${ }^{22}$ Like the genre as a whole, the testator was, to a certain extent, the result of literary convention, of fictionalisation, more a persona then an actual person. For example, a common characteristic in numerous literary testaments is that of the testator actually being too poor to bequeath anything. In the Grand Testament François Villon famously presents himself as a 'povre petit escollier' (1886); $;^{23}$ in her 'Wyll and Testament' Isabella Whitney points to her being 'whole in body, and in minde,/but very weake in Purse' (2) ${ }^{24}$ Likewise, De Dene's persona states from the outset that 'ken hebbe niet om gheuen huut kiste of schryne van ghelde of ander testamentelicke iuweelen' [I have no money or other testamentary jewellery in a chest or safe that I could give]. ${ }^{25}$

As a result of their impecuniosity the authors decide to make immaterial or mock bequests instead. In the Lais, Villon leaves rather futile things, such as 'Mes brayes' [my trousers] (101), 'plain pot de Saine' [water from the Seine] (228) and his 'chassiz tissus d'arigniee' [bed frame made of cobweb] (234). ${ }^{26}$ Whitney bequeaths things she does not actually possess: existing streets and buildings to the city of London, plasters to the surgeons (101-2), and her friends' intention to buy books from her printer $(197-200) ;{ }^{27}$ De Dene leaves the tail of a fox and three brooms to the Bruges Augustinians, so they can sweep their library, and a series of books in the 'filosofollie' ['philosofolly'] with nonsensical titles to the fool of the local archer's guild. ${ }^{28}$ The overall majority of his

${ }^{20}$ Huntington Rice, European Ancestry, 15; Boffey, 'Lydgate', 45.

${ }^{21}$ De Dene, Testament, I, 42.

${ }^{22}$ Cerquiglini-Toulet, L'ecriture testamentaire, 6-7.

23 Villon, Poésies, 152.

24 Clarke, Renaissance Women Poets, 19.

25 De Dene, Testament, II, 7.

26 Villon, Póesies, 43, 48, 49.

27 Clarke, Renaissance Women Poets, 22, 25.

${ }^{28}$ De Dene, Testament, I, 58, 231. The bequest of books with nonsensical titles has been interpreted as a reference to the Librairie de St. Victor in Chapter 7 of François Rabelais's Pantagruel. Dirk Geirnaert, 'Imitating Rabelais in 16th Century Flanders: The Case of Eduard de Dene', in Paul Smith [ed.], Éditer et traduire Rabelais à travers les âges [Amsterdam: Rodopi, 1997], 73-91. 
bequests, however, are his own poems and songs: 'maer van Rhetorica conste al wast my Pine elck tzyne//By desen testamente zou deelen' [but examples of the art of rhetoric, even if I find it difficult, through this testament I will share]. ${ }^{29}$

Villon scholars have often justly warned against too autobiographical a reading of his Testament. ${ }^{30}$ Adrian Armstrong called Villon's testator 'an unstable persona, who adopts a series of roles rather than a consistent stance'. ${ }^{31}$ We do, however, have to be careful not to let our understanding of a genre as a whole be dominated by the characteristics of its most famous example. As for the majority of authors from the time, biographical details about Eduard de Dene are scarce. Extra-literary sources about him do largely seem to conform to his persona in the Testament Rhetoricael, however. Most of the fellow rhetoricians he mentioned can be identified; his activities as a rhetorician and as a legal clerk are confirmed by other sources. The Bruges city archives possess an extensive court sentence from 1548 in which, because of Eduard de Dene's excessive drinking and gambling and the resulting neglect of his family, the full responsibility of the finances and possessions of the De Dene household is transferred to his wife. Three years earlier, as the archives also tell us, the author had already been briefly imprisoned for the same reasons. ${ }^{32}$

The existence of links between the Testament and historical sources should, of course, by no means imply that we can reduce a long and complex literary composition to a simple autobiographical utterance. It does suggest, however, that this literary testament is far more autobiographical then the two texts by Villon by which it was probably inspired. It also shows that by the middle of the sixteenth century, the genre of the literary testament had come to be able to function as a medium for genuine autobiographical writing.

\section{CARTOGRAPHY}

It was customary in medieval and early modern testaments to make donations to local religious and charitable institutions. In return, these entities would pray for the soul of the deceased. ${ }^{33}$ This type of bequest was also adopted in certain literary testaments, such as those by François Villon, Isabella Whitney, and Eduard de Dene. The fact that convents, hospitals, churches, and schools were

\footnotetext{
29 De Dene, Testament, II, 7.

${ }^{30}$ Jane H. M. Taylor, The Poetry of François Villon: Text and Context (Cambridge: Cambridge University Press, 2001), 33-57; Adrian Armstrong, 'The Testament of François Villon', in Simon Gaunt and Sarah Kay (eds.), The Cambridge Companion to Medieval French Literature (Cambridge: Cambridge University Press, 2008), 65-76.

31 Armstrong, 'The Testament', 64.

32 Gilbert Degroote, 'Eduard de Dene (1505- \pm 1578$)$ ', Leuvensche bijdragen op het gebied van de Germaansche philologie en in 't bijzonder van de Nederlandsche dialectkunde, 34 (1942), 126-41; Albert Schouteet, 'De Brugse rederijker Eduard de Dene', West-Vlaanderen, 12 (1963), 213-9.

33 Philippe Ariès, Het uur van onze dood: Duizend jaar sterven, begraven, rouwen en gedenken (Amsterdam: Elsevier, 1987), 190; Henk De Smaele, Onze-Lieve-Vrouwekerk te Brugge: Kunst en geschiedenis (Bruges: Jong Kristen Onthaal voor Toerisme, 1997), 118
} 
based at a specific location introduced a locational aspect in the texts. Institutions often simply became synonymous with their location. Thus Villon, in the Grand Testament, wonders what he could give 'à l'Hôtel Dieu' (1644-5), ${ }^{34}$ the hospital next to Notre-Dame on the Ile de la Cité. He leaves Mount Valerian, a pilgrim site outside of Paris, and a quarter of an indulgence he earned in Rome 'au mont de Montmartre' (1551-8), ${ }^{35}$ the famous hill in Paris where a female convent was based in Villon's day. Isabella Whitney also seems to refer to this custom when she leaves 'people [...] that out of tune doo talke' to 'Bedlam' (225-6), or St. Mary Bethlehem, formerly a priory and in Whitney's day already a hospital for the mentally ill then located near Bishopsgate in London. ${ }^{36}$

De Dene goes significantly further then both Villon and Whitney in making bequests to religious institutions. Of the 465 folios of his literary testament, 128 consist entirely of donations of this kind. He starts out with the four mendicant orders established in Bruges (Franciscans, Dominicans, Augustinians, and Carmelites), whom he wants to 'zyn ghedachtich' [remember]. ${ }^{37}$ He then continues with the eight parish churches that 'dienen oock verschoont' [also have to be endowed with something], since, as the author's persona remarks, 'diese wel doet/zal blyfuen niet ongheloont' [he who does them good will not remain without reward]. ${ }^{38}$ Then come a large number of smaller religious and charitable institutions, both inside and outside the city walls, such as Eekhout Abbey, the school of the Bruges Beghards, the Ten Wijngaerde Béguinage, or the chapel of the boatsmen. Most of the bequests that are mentioned in the collection can be related to these places in Bruges' urban space.

De Dene's bequests to churches, monasteries, chapels, schools, or hospitals are not only greater in number than those of Villon or of Whitney, his presentation of these religious and charitable institutions is also significantly more material and spatial in nature. When De Dene's persona mentions one, he seems to be thinking primarily of an actual building rather than of a more general location, an abstract community, or an administrative entity - what we today would call a 'legal personality'. This is apparent from, for example, the fact that the poet not only makes bequests to the institutions as a whole but also to parts of the buildings in which they are housed, such as a chapel, an altar, or a porch. At the monastery of the Carmelites, for example, he not only donates a Holy Virgin Lof to the Carmelite brothers but also a series of Holy Trinity refreinen to the chapel of the chamber of rhetoric De Heilige Geest [The Holy Ghost], of which he was a member. ${ }^{39}$ He also remembers people who were attached to or lived near a building. For the principal bell-ringer of Saint-Donatian, for example, De Dene wishes that he may be attributed an assistant bell-ringer for when he

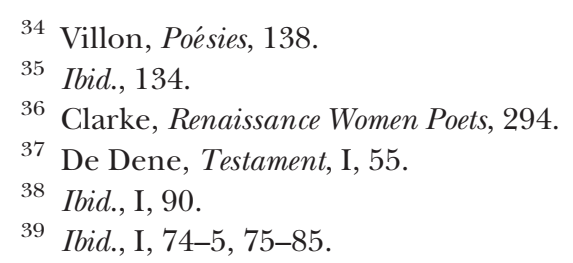


has been drinking. Nietken 'de naeysterghe' [the seamstress], 'by sint donaes wuenende in een cleen wynckelken' [who lived near Saint-Donatian in a small shop] receives 'diueersch moy duerbroddelt naeysel' [diverse kinds of nicely messed-up needlework]. ${ }^{40}$

The outspokenly material and spatial presentation of monasteries and churches in the Testament Rhetoricael is also apparent from the fact that the order in which buildings are mentioned seems to have been determined primarily by their spatial proximity to one another. This cannot only be observed in the evocation of the institutions themselves but also in that of buildings that were located in their vicinity. While speaking of the church of Our Lady, for example, the poet's persona also mentions nearby Saint John's hospital, as well as Eekhout Abbey. ${ }^{41}$

The principle of vicinity is essential to the autobiographical nature of the Testament Rhetoricael. It is also a characteristic that sets the collection apart from Villon's Lais and Grand Testament. As we have seen above, individual places to which bequests are made trigger loose memories and opinions in the mind of De Dene's persona. It is in the mental wandering along these places, however, that the autobiographical narrative takes shape. Specific individuals, groups, events, opinions, or character traits of the author are referred to in connection to distinct places, which allows the reader to make connections and distil the autobiographical narrative. The author's life is presented not chronologically, as in most modern writings about the self, but chorographically, on the basis of how aspects of the author's self can be linked to a specific circuit of places. His Testament thus reveals a sense of space and a capacity to imagine and evoke space that Villon, an earlier practitioner of the genre of the literary testament, either did not have or did not think interesting or relevant enough to express in his writings. In the French poet's Lais and Grand Testament, the few spaces that are mentioned remain loose dots, while the autobiographical nature of De Dene's Testament lies precisely in the connections between the dots.

It is tempting to link De Dene's chorographical self-writing to the genre of the urban chorography, or textual description of cities. ${ }^{42}$ Like the Testament Rhetoricael, urban chorographies link people and events from a city's past to spaces and places from its present. The possibility cannot be excluded that De Dene might have been familiar with early vernacular examples of the urban chorography, such as La Fleur des antiquitez (1532) and Les Antiquitez, chroniques, et singularitez de Paris by Gilles Corrozet (1550). ${ }^{43}$ However, most urban chorographies and the earliest descriptions of this kind of cities in the Low Countries,

40 Ibid., I, 90-1.

41 Ibid., I, 108.

42 On the genre of the chorography, see, for example, Richard Helgerson, Forms of Nationhood: The Elizabethan Writing of England (Chicago: University of Chicago Press, 1994); Eddy Verbaan, De woonplaats van de faam: Grondslagen van de stadsbeschrijving in de zeventiende-eeuwse Republiek (Hilversum: Verloren, 2011); and Raingard Esser, The Politics of Memory: The Writing of Partition in the Seventeenth-Century Low Countries (Leiden: Brill, 2012).

${ }^{43}$ Cynthia Skenazi, Le poète architecte en France: Constructions d'un imaginaire monarchique (Paris: Champion, 2003), 117-43. 
such as Lodovico Guicciardini's Descrittione di tutti $i$ Paesi Bassi (first Italian edition: 1567; first translation into Dutch: 1612) and Jan Orlers' Beschrijuinge der stad Leyden (1614), are younger than the Testament. ${ }^{44}$

A second possible source of inspiration for De Dene's chorographic selfwriting comprises religious processions and joyous entries of princes. These parades followed specific routes through the city, linking important places for the cities' past or present, or symbolically demarcating a specific zone. ${ }^{45}$ As in the Testament, their movement through urban space can thus be read as an expression of identity. De Dene was actively involved in the organisation of processions and joyous entries. In his Testament he included several texts, mostly songs, written for performance during the city's yearly procession of the Holy Blood. ${ }^{46}$ In 1549 he and the painter Pieter Pourbus conceived the decorations organised by the Franc of Bruges for the Joyous Entry into the city of Charles V and his son, the future Philip II. ${ }^{47}$

Religious processions and especially princely entries into cities were commonly recorded in writing, both in chronicles and in separate booklets. ${ }^{48}$ In 1515, for example, the Bruges rhetorician Jan de Scheerere, a friend of De Dene who is commemorated in his Testament, ${ }^{49}$ composed a detailed evocation in verse of the joyous entry of Charles $\mathrm{V}$ into the city in that same year. ${ }^{50}$ These descriptions of processions and joyous entries are among the earliest written evocations of a movement through urban space.

The significance of the differences and correspondences between processions and princely entries on the one hand and De Dene's chorographic autobiography on the other can perhaps best be understood through Michel de Certeau's exceptionally rich and stimulating theoretical reflection on the meaning of space in 'Pratiques d'espace', the third part of his L'invention du quotidien. 1. arts de faire. ${ }^{51}$ De Certeau opens his essay with an evocation of the view on Manhattan from the 110th floor of the (former) World Trade Center

\footnotetext{
${ }^{44}$ Lodovico Guicciardini, Descrittione di tutti i Paesi Bassi (Antwerp: Willem Silvius, 1567); Jan Orlers, Beschrijvinge der stad Leyden (Leiden: H. Haestens, J. Orlers ende J. Maire, 1614). Some chronicles from before 1562 do contain chorographic passages, however, such as the chronicle of Zeeland by Jan Reygersberch (Antwerp: vid. Heyndrick Peetersen van Middelburch, 1551).

${ }^{45}$ Elodie Lecuppre-Desjardin, La ville des cérémonies: Essai sur la communication politique dans les anciens PaysBas bourguignons (Turnhout: Brepols, 2004).

46 De Dene, Testament, I, 117-20.

47 Katarina De Fruyt, Blijde intredes van vorsten in Brugge 1497-1549 (MA thesis, Ghent University, 1998), 129-31; Luc Devliegher, 'De blijde intrede van prins Filips in 1549', Handelingen van het genootschap voor geschiedenis te Brugge, 136 (1999), 124-5.

${ }^{48}$ Helen Watanabe-O'Kelly, 'The Early Modern Festival Book: Function and Form', in J. R. Mulryne, Helen Watanabe-O'Kelly, and Margaret Shewring (eds.), Europa Triumphans: Court and Civic Festivals in Early Modern Europe, 2 vols. (Aldershot: MHRA, 2004), I, 3-17.

49 De Dene, Testament, II, 7-10.

50 [Jan de Scheerere,] De triumphe ghedaen te brugghe binnen Ter intreye van caerle (Antwerp: Adriaen van Berghen, 1515). Modern edition in Samuel Mareel, 'Jan de Scheereres Triumphe ghedaen te brugghe ter intreye van caerle: Teksteditie met inleiding en aantekeningen', Jaarboek 'De Fonteine', 55 (2005), 79-143.

51 De Certeau, L'invention du quotidien, 137-91.
} 
in New York City. Most of the essay consists of an analysis of the differences between the perception of the city from such a height and that of someone who finds himself on the actual streets below. The primary difference, according to De Certeau, lies in the act through which the city is experienced. In the first case it is through looking, more precisely through 'l'oeil totalisant' [the totalising eye] that takes in the entire cityscape ${ }^{52}$ in the second it is through a more physical activity, namely walking. It is by walking through the city, through individual streets and along individual buildings - what De Certeau calls 'une rhétorique de la marche ${ }^{, 53}$ [a rhetoric of walking] - that people 'en bas' [down below] give meaning to the city.

The element of walking is essential to capture the difference between processions and princely entries and their evocations in writing on the one hand and De Dene's Testament on the other. Walking is central to the procession; it is what binds together both its participants and the places they pass by. Although, as we have seen, De Dene's evocation of churches and monasteries is guided by spatial proximity, walking is entirely absent from his Testament. At several points in the text he emphatically evokes himself sitting in his bedroom, thinking and writing his testament. ${ }^{54} \mathrm{He}$ does not experience the city like De Certeau's twentieth-century Manhattan pedestrians or like his sixteenth-century contemporaries participating in a procession or joyous entry; rather, he overlooks it through his 'totalising' mental eye. His Testament is primarily a report of a mental activity, while evocations in writing of processions or joyous entries are reports of physical activities.

De Certeau explicitly relates the view from the 110th floor of the World Trade Center to medieval and Renaissance paintings half a millennium earlier that already offered a comparable perspective on cities. 'The desire to see the city', he writes, 'preceded the means of satisfying it. Medieval or Renaissance painters represented the city as seen in a perspective that no eye had yet enjoyed'. ${ }^{55}$ This link between the totalising but immobile eye and late medieval and early modern city panoramas and cartography is highly relevant for De Dene's Testament. From about the same time as when De Dene composed his collection, several visual works of art have come down to us that show a comparable 'totalising eye' on the city of Bruges. They are part of a larger explosion of cartographic interest in the Low Countries around the middle of the sixteenth century. An artificial panorama, dated about 1560 and attributed to the painter Pieter Claeissens the Elder, shows, from an elevated viewpoint, the seven most

\footnotetext{
52 Ibid., 141.

${ }^{53}$ Ibid., 149.

${ }^{54}$ De Dene, Testament, I, 48; cf. Ibid., II, 242, where he made a rat jump up when he moved about at his desk ['My verRoerende deed ick een Ratte versprynghen'].

55 'La volonté de voir la ville a précédé les moyens de la satisfaire. Les peintres médiévales ou renaissantes figuraient la cité par un oeil qui pourtant n'avait encore jamais existé. De Certeau, L'invention du quotidien, 140. The English translation is borrowed from Simon During, The Cultural Studies Reader (London: Routledge, 1993), 157.
} 
important buildings in Bruges. ${ }^{56}$ From the 1540s and 1560s, three important maps of Bruges have come down to us: an anonymous one painted on canvas and dated shortly after 1546 , one from the famous cartographer Jacob van Deventer from the 1560s, and a third one, dated 1562, by the Bruges painter and printmaker Marcus Gerards the Elder. The cityscape by Claeissens, the anonymously painted map, and the Gerards map were probably made to promote the city of Bruges, which was being increasingly confronted with economic difficulties; the Van Deventer map is part of a systematic cartography of all the cities of the Netherlands that was commissioned by Philip II in 1559. ${ }^{57}$

The most significant link between these visual works of art and Eduard de Dene is the map of Marcus Gerards. This painter, engraver, and cartographer made his map by commission of the city administrators between the summers of 1561 and 1562, so during exactly the same period when Eduard de Dene wrote down his literary testament. Although De Dene does not refer explicitly to the map in his collection, it is certain that the two artists knew each other. In 1567, the Bruges printer Pieter de Clerck published De Warachtighe fabulen der dieren, a collection of animal fables by Eduard de Dene accompanying a series of copper engravings by the same Marcus Gerards. ${ }^{58}$ The two artists seem to have been closely acquainted. In 1577, almost ten years after Gerards had fled to England because of his Reformed sympathies, De Dene intervened on his behalf before the Bruges magistrate in a conflict over payment for work that Gerards had done in 1566 in the church of Our Lady. ${ }^{59}$

Over the last few decades a number of studies, notably by Tom Conley, have analysed the far-ranging influence of cartography on early modern literature. It seems highly likely that the Testament Rhetoricael has received what Conley, in The Self-Made Map, called a 'cartographic impulse' ${ }^{60}$ It is possible to actually follow the series of buildings and locations evoked in the Testament Rhetoricael on the map of Marcus Gerards. It is an attractive thought that the poet and the engraver might have been in touch with each other while working on their literary testament and map, and that there has been some form of crossfertilisation. The strongly material and spatial evocation of the Bruges churches and monasteries in the Testament could be explained by De Dene's acquaintance with Gerards' map of Bruges, which not only shows these buildings in

\footnotetext{
56 Eva Tahon, '117. Les sept merveilles de Bruges', in Maximiliaan P.J. Martens (ed.), Bruges et la Renaissance: De Memling à Pourbus. Vol. II: Notices (Bruges: Stichting Kunstboek, 1998), 148.

57 Marc Ryckaert, '152. Plan de Bruges', in Martens (ed.), Bruges et la Renaissance, 173-4; Eva Tahon, '154. Plan de Bruges', in Martens (ed.), Bruges et la Renaissance, 175-6. Van Deventer already made an earlier series in 1545: http://bdh-rd.bne.es/viewer.vm?id=0000015403 (accessed April 2016).

58 Dirk Geirnaert and Paul J. Smith, 'The Sources of the Emblematic Fable Book De warachtighe fabulen der dieren (1567)', in John Manning, Karel Porteman, and Marc van Vaeck (eds.), The Emblem Tradition and the Low Countries: Selected Papers of the Leuven International Emblem Conference, 18-23 August 1996 (Turnhout: Brepols, 1999), 23-38.

59 Albert Schouteet, De zestiende-eeuwsche schilder en graveur Marcus Gerards (Bruges: Gidsenbond, 1941), 29-30, 63-4.

${ }^{60}$ Conley, The Self-Made Map, 2.
} 
their geographical relation to each other but, through their pictorial representation, also in their materiality.

However, the Gerards map might have shaped De Dene's thinking on a more abstract level as well. Several scholars, such as Elizabeth Eisenstein, have argued that the development of cartography has stimulated the development of national identities during the early modern period. ${ }^{61}$ By being able to take in the whole of a country visually, people could identify more easily with the concrete stretch of land that corresponded to this abstract political entity. Eduard de Dene probably did not need a map of Bruges to feel attached to this city but it might have given his Bruges identity the kind of spatial, geographical component that is apparent from the Testament Rhetoricael, and it might have stimulated him to give his literary testament such a spatial and material aspect.

\section{URBAN SPACE, MEMORY, MONUMENT}

As we have seen above, the main link in the Testament Rhetoricael between place and self lies in the association by the author of contemporary places with events or people that were important to him in the past. This link is generally triggered by memory: seeing or mentioning a specific place reminds De Dene's persona of people or events. The churches, chapels, and monasteries mentioned thus constitute a material link between the author's individual present and his individual past. They are what Michel de Certeau, in the essay on space already quoted above, called 'lieux vécus' [lived spaces] and further defined as 'des présences d'absences' [presences of absences]. ${ }^{62}$

The memory process that I have just evoked is essentially a personal and random one: different people will remember different things at different places. Had a contemporary of De Dene written a comparable literary testament in which he passed by the same Bruges churches, monasteries, chapels, schools, and hospitals, he would most probably have come up with a significantly dissimilar narrative.

The association of current places with past people or events is not necessarily personal and random, however. It can also be brought about externally and intentionally. While mentally wandering from one place to another, De Dene's persona bequeaths his poems and songs. In some cases he states explicitly that a text is to be posted in a specific location. Some of these are prayers to be read in a certain part of a church or chapel, or in the vicinity of a relic or an altar dedicated to a specific saint or to the Holy Sacrament. Other texts, however, have a less devotional but more outspoken commemorative function. For example, in his Testament De Dene included a series of epitaphs that he wrote for deceased friends and fellow rhetoricians, such as the playwright Cornelis

\footnotetext{
${ }^{61}$ Elizabeth Eisenstein, The Printing Revolution in Early Modern Europe (Cambridge: Cambridge University Press, 2005), 144.

${ }^{62}$ De Certeau, L'invention du quotidien, 162.
} 
Everaert and the painter Lancelot Blondeel. ${ }^{63}$ At the end of the Testament the author also included two epitaphs for himself. ${ }^{64}$ Deictic references to an actual tomb and direct addresses to the reader suggest that at least some of De Dene's epitaphs might have adorned actual places of burial. ${ }^{65}$ Tombs from early modern Bruges with rhetoricians' poems on them have also come down to us. The Saint-John's hospital museum, for example, houses a commemorative plaque for the Bruges town councillor Pieter van Muelenbeke (died in 1480). It is engraved with a 23-verse Dutch poem, which includes an acrostic and a chronogram, two characteristics that are typical of rhetoricians' poetry. ${ }^{66}$

Several of De Dene's epitaphs contain an outspoken appeal to remember somebody at a specific location. For example, the author's persona indicates that he bequeaths these poems to his deceased friends 'vpdatmen hemlieden/ mach zyn ghedynckende' [so that they may be commemorated].$^{67}$ In the introductions to the two epitaphs he wrote for himself he notes that he hopes his widow will have the longer epitaph of the two placed somewhere 'Teender memorie' [as a commemoration]. ${ }^{68}$ ' [W] aere dit te lanck of te groote cost' [If this proves to be too expensive or the epitaph is too long], he also provides a shorter one and adds: 'Doet tnaeruolghende naglen/An muer of post' [have it nailed to a wall or a pole]. ${ }^{69}$

In the epitaphs that De Dene wrote for posting in a public space, his Testament Rhetoricael is not only a product of memory, it also reports on the active process of the creation of memory. De Dene wrote the epitaphs so that not just he might remember the deceased, but others too who pass by the objects to which these verses have been attached. These texts bear witness to a transition from individual living memory to a more artificial cultural memory. In Cultural Memory and Western Civilization Aleida Assmann defined cultural memory as a form of memory 'that is underpinned by media - by material carriers such as memorials, monuments, museums, and archives'. It is a form of memory that is 'reconstructed within a transgenerational framework, and on an institutional level, within a deliberate policy of remembering or forgetting, ${ }^{70}$ These poems are such a kind of material carrier in which individual memory is transformed into a public memorial.

De Dene's epitaphs can be situated within a longstanding memorial tradition in Netherlandish rhetoricians' culture. An important part of the religious practices of the rhetoricians consisted in the organisation of commemorative

63 De Dene, Testament, II, 7-22.

64 Ibid., III, 219-20.

${ }^{65}$ Samuel Mareel, 'Inscription et Performance dans le Testament Rhetoricael d'Eduard de Dene (Bruges, 1562)', Le Moyen Age, 122 (2016), 327-39.

${ }^{66}$ Valentin Vermeersch, Grafmonumenten te Brugge voor 1578, 3 vols. (Bruges: Raaklijn, 1976), II, 287-9.

67 De Dene, Testament, II, 7.

68 Ibid., III, 219.

69 Ibid.

70 Aleida Assmann, Cultural Memory and Western Civilization (Cambridge: Cambridge University Press, 2011), 6 . 
services for deceased members. Famous fifteenth- and early sixteenth-century rhetoricians, such as Anthonis de Roovere and Matthijs de Castelein, commemorated deceased princes as well as fellow rhetoricians in their poems. ${ }^{71}$ From the middle of the sixteenth century onwards, however, this memorial tradition seems to have increasingly invaded urban public space. In the process, it also became more material and monumental. Inscriptions on the walls of public buildings were not new, of course. Traditions of inscriptions from antiquity spread throughout Christian Europe during the Middle Ages and enjoyed a renewed interest in the sixteenth century because of the influence of humanism. This is almost uniquely a Latin tradition, however. In texts such as De Dene's Testament Rhetoricael, we are witnessing the increased use of the vernacular for inscriptional poetry in urban public space.

The growing interest in poetry in urban space as a medium for the creation and reception of cultural memory is apparent not only from the increasing number of poems of this kind that seem to have been produced, but also from a renewed antiquarian interest in these kinds of texts. Many inscriptions were copied out in the chorographic descriptions of cities that became increasingly popular across Europe from the late sixteenth century onwards, such as the already mentioned Beschrijuinge der stad Leyden (1614) by the Leiden author, and later mayor, Jan Orlers, or John Stowe's 1598 Survay of London. Most of the texts mentioned in these chorographies disappeared with the architectural structures that they adorned. Some of them did come down to us, however. In his Beschrijuinge der stad Leyden Jan Orlers included a long chronogram composed by his uncle Jan van Hout on the 1574 siege of Leiden. The text can still be seen on Leiden's city hall today.

\section{CONCLUSION}

Few tourists visiting present-day Bruges venture beyond Saint-John's Hospital and the Church of Our Lady just across the Katelijnestraat. Those who do continue on this street, however, are rewarded by the discovery of the charming Bruges Academy of Fine Arts, a complex of buildings dating from the sixteenth to the nineteenth centuries. Centrally located in the Academy is the Bogardenkapel. This small structure is a reminder of the original function of the institution as a school for orphans and abandoned children run by the Bruges bogarden [beghards], a kind of male Beguine. Above the entry to the chapel is a stone slab with a chronogram that has been identified as having been

\footnotetext{
${ }^{71}$ On the commemorative practices of the Dutch rhetoricians, see Samuel Mareel, 'In the Book of Life: Manuscript, Memoria, and Community in Eduard de Dene's Testament Rhetoricael (Bruges, 1562)', The Sixteenth Century Journal, 43 (2012), 1013-35. On the creation of cultural memory by the rhetoricians, see also Arjan van Dixhoorn, 'Monumentalizering van een festival: Het Antwerpse landjuweel van 1561 als historische gebeurtenis', in Jeroen Vandommele and Ruud Ryckaert (eds.), Menich constich gheest: Het Antwerpse landjuweel van 1561 anders bekeken (Ghent: Koninklijke Soevereine Hoofdkamer van Retorica 'De Fonteine', 2014), 15-42 [Jaarboek 'De Fonteine', 53-4 (2011-2012)].
} 
composed by Eduard de Dene to commemorate a lottery organised in 1549 to help finance the restoration of the buildings. ${ }^{72}$

It is a small miracle that the slab and its chronogram came down to us. De Dene did not include the poem in his Testament Rhetoricael, nor has it been found in any other written or printed source. Presumably he did not think it sufficiently accomplished or important. Moreover, the chapel on which it has been attached is significantly younger than the slab itself. It was built in 1676 on the location of the original chapel for which De Dene wrote his chronogram. Apparently the slab was conserved and reintegrated in the facade of the new building. That De Dene's chronogram for the Bruges Beghards should have survived, however, as a textual object in its original location, is a fitting tribute to an author for whom - as I have tried to show in this essay - literature, identity, and location were so intimately intertwined.

The slab functions as a sort of complement to Elisabeth Hodges's notion of 'urban poetics' that stood at the outset of this essay. It can also be seen as its ultimate realisation. De Dene's chronogram above the entry door of the chapel of the Bruges Academy of Fine Arts does not attest to 'the way the city functioned in early modern texts as [...] a means by which authors expressed the self as a phenomenon related to location', but rather to the way early modern texts functioned in the city as a means by which authors expressed the self as a phenomenon related to location. Rarely in the history of Dutch literature has the boundary between text and city been more porous.

\section{Museum Hof van Busleyden/Ghent University}

\footnotetext{
72 Dirk Geirnaert, 'Restauratie met rekenfout: Eduard de Denes chronogram voor de Bogardenschool', Biekorf, 111 (2011), 186-91. The text reads: 'Met pennynghen, ghegadert ter loterie / Bij die vander boghaerde vry vpghestelt, / Was dit werck beghonnen, zoot elck anzie. / Leist de roode letteren: tjaer ghij telt.' [With pennies, brought together during the lottery, that was organised by the beghards, this work has been initiated, as anyone can see. Read the red letters: you will count the year.]
} 